International Journal of Business Management and Economic Review

Vol. 4, No. 04; 2021

ISSN: 2581-4664

\title{
THE EFFECT OF WORK ENGAGEMENT AND JOB SATISFACTION ON WORK MOTIVATION AND ITS IMPACT ON CAREER DEVELOPMENT OF REGIONAL SECRETARIAT EMPLOYEE IN SIMEULUE DISTRICT
}

\author{
Asmul Hirma, Mukhlis and Said Musnadi \\ Management Department, Universitas Syiah Kuala, Indonesia \\ http://doi.org/10.35409/IJBMER.2021.3281
}

\begin{abstract}
This study intends to examine the effect of work engagement and job satisfaction on work motivation and its impact on career development for employees of the Regional Secretariat of Simeulue Regency (Setdakab Simeulue). The population of this research was all employees of Setdakab Simeulue, totaling 127 people. Sampling was done by using the census technique. Data were collected using a questionnaire and analyzed using the Structural Equation Modeling (SEM) method. The research results reveal that in the Setdakab Simeulue, it is proven that work engagement significantly affects career development, job satisfaction significantly affects employee career development, work engagement significantly affects work motivation, job satisfaction significantly affects work motivation, work motivation significantly affects career development, work engagement significantly affects career development through work motivation, and job satisfaction significantly affects career development through work motivation. From the results of the model test analysis, it was also found that the work motivation variable functions as a partial mediator. These findings have proven that in the career development model at the Setdakab Simeulue, it is necessary to strengthen work management and job satisfaction of employees so that they are able to boost their work motivation, and have an impact on strengthening the career development of employees. Future researchers are expected to develop this tested model by adding other variables such as talent management and human capital management.
\end{abstract}

Keyword: Work Engagement, Job Satisfaction, Work Motivation, Career Development.

\section{INTRODUCTION}

A career is often seen as a journey from job to job that is part of a carefully crafted plan. Career development is closely related to the development of human resources in an organization and is a very important part of an organization. However, this has not happened to the Regional Secretariat of Simeulue Regency (Setdakab Simeulue). This is evident from the results of the initial survey that the researcher has conducted where the results are 2.85 on the Likert scale. These results indicate that career development is still not going well. One of the factors causing low career development is work motivation.

Based on the observations made by the author at the Setdakab Simeulue, which is one of the Indonesian government institutions in Simeulue Regency, it turns out that its employees still 


\section{International Journal of Business Management and Economic Review}

Vol. 4, No. 04; 2021

ISSN: 2581-4664

have not shown work motivation as expected by the leadership and the expectations of the community, especially in improving services to the community in the Regency of Simeulue. The low work motivation of employees can be seen from the service procedures provided by employees to the community which are still overlapping, the service requirements provided are often inconsistent, the responsibility of service officers to the community is also not good, then the problem of service schedule certainty also changes sometimes.

One of the factors that can affect the improvement of career development and also employee motivation is the existence of employee work engagement. In this era, work engagement has become an important topic for an organization or company where work engagement has been the subject of discussion by many management experts in recent years.(Saks, 2006). Another factor that affects work motivation and has an impact on career development is job satisfaction. Therefore it is important for the Setdakab Simeulueto meet the needs of employees and create work comfort to increase work motivation better. Based on the above, the authors conducted research using variables of Work Engagement, Job Satisfaction, Work Motivation, and Career Development with the research location at Setdakab Simeulue.

\section{LITERATURE STUDY Career development}

Career development can have an impact on employee performance because career development is a formal approach that companies take intending to ensure that employees have the required qualifications and abilities and experience(Kaseger, 2013). Career planning and development programs focus on helping employees achieve the essential competencies in career development, knowledge, skills, and abilities needed to make effective career decisions (Amin, Ismail, Rasid, \& Selemani, 2014).

(Zainal, 2015)stated that career development is influenced by several factors, namely competence, reward system, work engagement, job satisfaction, and work motivation. In this research, career development uses indicators as disclosed by(Zainal, 2015)who stated that career development is influenced by several factors, namely competence, reward system, work engagement, job satisfaction, and work motivation. In this research, career development uses indicators as disclosed by.

\section{Work motivation}

Motivation can be expressed as something that is needed by everyone in running life, helping others, leading a group of people, and achieving the desired goals(Robbins, Coulter, \& Cenzo, 2019). In everyday life, motivation is often interpreted as the whole process of giving encouragement or stimulation to employees, so that they are willing to work willingly without feeling forced(Herzberg, Mausner, \& Snyderman, 2011). Meanwhile(Hagemann, 2013)mentioned motivation as a tendency in a person that increases endurance and directs his behavior. In this research, work motivation is measured using indicators as disclosed by(Robbins et al., 2019)namely job satisfaction, status and responsibilities, adequate benefits, working environment conditions, work facilities, personal desires, and expectations.

\section{Job satisfaction}

(Furnham, Petrides, Jackson, \& Cotter, 2002)defined job satisfaction as the extent to which 


\section{International Journal of Business Management and Economic Review}

Vol. 4, No. 04; 2021

ISSN: 2581-4664

they are satisfied with their work. (Soetrisno, 2016)mentioned job satisfaction is an employee's attitude towards work related to work situations, cooperation between employees, rewards received in work, and matters relating to physical and psychological factors. (Sopiah \& Sangadji, 2018)described job satisfaction as a person's emotional response to work situations and conditions. In this research, the measurement of job satisfaction uses indicators as expressed by(Koh \& Boo, 2001)namely compensation, promotion, teamwork, supervisors, and jobs.

\section{Work Engagement}

(Robbins et al., 2019)stated the definition of work engagement, which is where an employee is said to have work engagement in his job if the employee can identify himself psychologically with his job, and consider his performance important to himself, in addition to the organization. Research on engagement in work has resulted in four different defining constructs and measurement methods, including personal engagement, work engagement, burnout/engagement, and work engagement(Freudenberger, 1974).

Meanwhile(Kahn, 1990)mentioned personal engagement and personal disengagement as behaviors that people carry or leave in them while working. However, even though there are many opinions regarding the factors included in work engagement, there is still a lack of clarity about the definition and measurement of work engagement(Robertson \& Cooper, 2010). In this research work engagement is measured using indicators as disclosed by(Albrecht, 2010)namely knowing what is expected, having work equipment, having the opportunity, receiving awards, caring for the leadership.

\section{Conceptual Framework and Hypotheses}

The research conceptual framework and the results of the research hypothesis formulation can be described as follows :

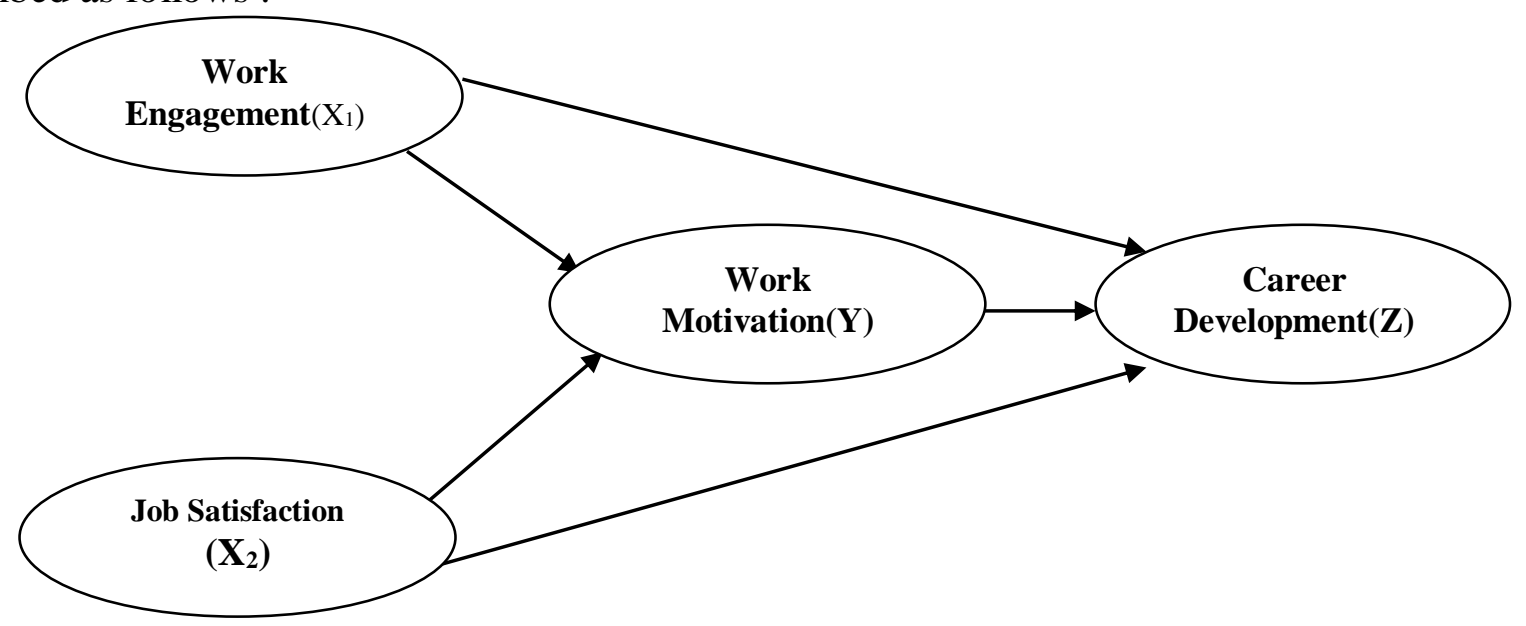

Figure 1. Conceptual Framework

Ha1: Work engagement significantly affects career development $\mathrm{Ha} 2$ : Job satisfaction significantly affects career development Ha3: Work engagement significantly affects work motivation 
International Journal of Business Management and Economic Review

Vol. 4, No. 04; 2021

ISSN: 2581-4664

Ha4: Job satisfaction significantly affects work motivation

Ha5: Work motivation significantly affects career development

Ha6: work engagement significantly affects career development through work motivation

Ha7: Job satisfaction significantly affects career development through work motivation

\section{RESEARCH METHOD}

The research was carried out at the Setdakab Simeulue. The objects of research are work engagement, job satisfaction, work motivation, and career development. The population of this research was all employees of Setdakab Simeulue, totaling 127 people. The sample took the entire population (census) as research respondents.

The data was collected using a questionnaire, the data was measured using a Likert scale, and the data were analyzed using the Structural Equation Modeling (SEM) method. Mathematically, the causality relationship between constructs in research can be stated as follows:

$\eta=\gamma 1.1 \xi 1+\gamma 1.2 \xi 2+\zeta 1$

$\eta=\gamma 2.1 \xi 1+\gamma 2.2 \xi 2+\beta 21 \eta 2+\xi 2$

or:

Work Motivation $=\gamma 11$ work engagement $+\gamma 12$ Job Satisfaction $+\zeta 1$

Career development $=\gamma 21$ work engagement $+\gamma 12$ Job Satisfaction $+\gamma 13$ Work Motivation $+\zeta 2$

Testing was done in 2 (two) ways, namely direct effect hypothesis testing and indirect effect hypothesistesting with work motivation as the mediator variable. Testing the mediating effect in this research used an approach(Baron \& Kenny, 1986), by using the Sobel calculator.

\section{RESULT}

\section{Direct Hypothesis Testing}

The structural model analysis that explains the effect test between variables is presented in the following path diagram:

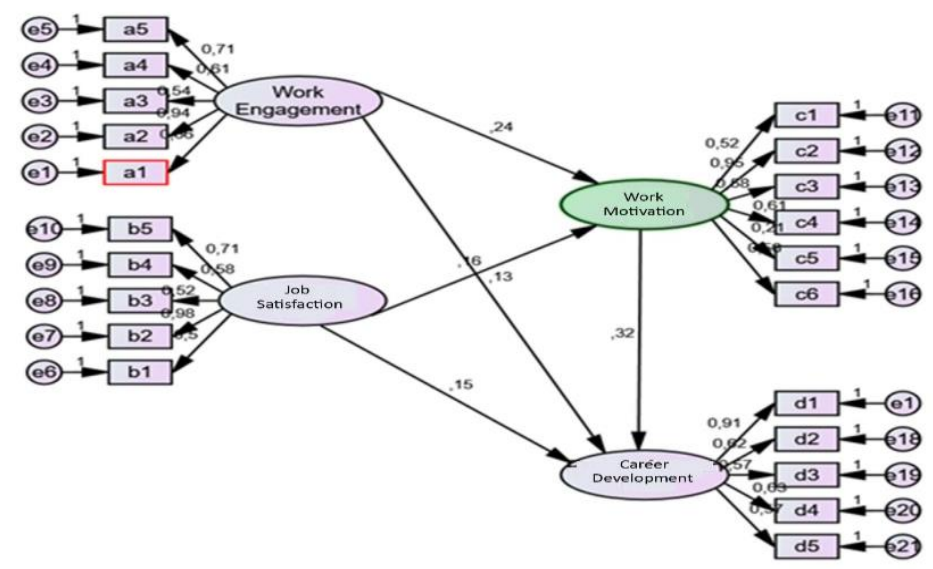

Figure 2. Full SEM Model 


\section{International Journal of Business Management and Economic Review}

Vol. 4, No. 04; 2021

ISSN: 2581-4664

The test results of the full model for testing the direct effect hypothesis after fulfilling the SEM assumptions are more clearly shown in the following table:

Table 1. Direct Hypothesis Test Results

\begin{tabular}{|lll|lll|}
\hline & & & Estimate & C.R. & P \\
\hline Work Motivation & $<---$ & Work_Engagement & 0.249 & 5.415 & $* * *$ \\
Work Motivation & $<---$ & Job Satisfaction & 0.161 & 6.824 & $* * *$ \\
Career development & $<---$ & Work_Engagement & 0.133 & 5.041 & $* * *$ \\
Career development & $<---$ & Job Satisfaction & 0.151 & 3.101 & $* * *$ \\
Career development & $<---$ & Work Motivation & 0.323 & 7.375 & $* * *$ \\
\hline
\end{tabular}

Source: Primary data, 2021 (processed)

From the test findings in table 1, it can be explained as follows:

1. H1: Testing the Influence of Work Engagement on Career Development for Setdakab Simeulue employees produced a Critical Ratio (CR) value of 5.415 with a probability (pvalue) of 0.002 . The two values state that $\mathrm{H} 1$ is acceptable because it has met the requirements for the $\mathrm{CR}$ result limit and the $\mathrm{p}$-value, namely the $\mathrm{CR}$ value> 1.96 and the $\mathrm{p}$ value $<0.05$. These results conclude that work engagement affects the career development of Setdakab Simeulue employees. This also reveals that the higher the level of work engagement of the Setdakab Simeulueemployees will have a positive impact on improving the career development of Setdakab Simeulueemployees, especially in improving the work results of all employees in the organization. Research results are also relevant and consistent with the findings of research conducted by(Bigliardi, Petroni, \& Dormio, 2005)which proved that the work engagement possessed by employees also has an impact on the career development of an employee in a company or organization.

2. H2: Testing the Effect of Job Satisfaction on Career Development for Setdakab Simeulue employees resulted in a CR value of 6.824 with a p-value of 0.042 . The two values state that $\mathrm{H} 2$ is acceptable because it has met the requirements for the CR result limit and the pvalue, namely the $\mathrm{CR}$ value $>1.96$ and the $\mathrm{p}$-value $<0.05$. These results conclude that the employee job satisfaction felt by all Setdakab Simeulueemployees influences on improving employee career development, especially in providing services to the community in Setdakab Simeulue. The results of this research are relevant and consistent with the findings of research conducted by(Wickramasinghe \& Jayaweera, 2010)which stated that career planning is positively related to career strategy, career strategy is positively related to professional enhancement, and professional enhancement is positively related to career development.

3. H3: Testing the Effect of Work Engagement on Work Motivation of Setdakab Simeulueemployees produces a CR value of 5.041 and a p-value of 0.023 . The two values state that $\mathrm{H} 3$ can be accepted because it has met the requirements for the CR result limit and the $\mathrm{p}$-value, namely the $\mathrm{CR}$ value $>1.96$ and the $\mathrm{p}$-value $<0.05$. These results conclude that the work engagement of Setdakab Simeulueemployees affects employee work motivation. This also reveals that better work engagement will have a positive and real impact on increasing the work motivation of Setdakab Simeulue employees. The results of 
this research are relevant and consistent with the results of previous research conducted by Anogoro (2014) that a job in relation to performance achievement will be greatly influenced by the underlying motivation of humans to do work

4. H4: Testing the Effect of Job Satisfaction on Work Motivation at Setdakab Simeulue resulted in a CR value of 3.101 with a p-value of 0.000 . The two values state that $\mathrm{H} 4$ can be accepted because it has met the requirements for the CR result limit and the p-value, namely the $\mathrm{CR}$ value $>1.96$ and the p-value $<0.05$. These results conclude that the job satisfaction felt by employees at the Setdakab Simeuluehas an effect on the work motivation of employees at the Setdakab Simeulue. This indicates that the higher the job satisfaction felt by employees will further increase employee motivation. The results of this research are relevant and consistent with research conducted by Yee (2021), which stated that there is a relationship with a positive direction and a significant influence between motivation and job satisfaction.

5. H5Testing the Effect of Work Motivation on Career Development of Setdakab Simeulueemployees resulting in a CR value of 7.375 with a p-value of 0.000 . The two values state that $\mathrm{H} 5$ is acceptable because it has met the requirements for the $\mathrm{CR}$ result limit and the $\mathrm{p}$-value, namely the $\mathrm{CR}$ value $>1.96$ and the $\mathrm{p}$-value $<0.05$. These results conclude that employee work motivation affects career development at Setdakab Simeulue. This indicates that the higher the work motivation of the employees of Setdakab Simeuluewill further enhance career development because each employee will be motivated to achieve better work results. The results of this research are consistent with research conducted by Zainun (2014), which revealed that motivation can be seen as an integral part of personnel administration in the process of coaching, developing, and directing the workforce in an organization.

\section{Indirect Hypothesis Testing (Mediation)}

The results of testing the indirect hypothesis (mediation) are described below:

1. H6: Testing the effect of Work Engagement and Job Satisfaction on Career Development through Work Motivation aims to prove whether the influence is significant or not. Testing the mediating effect in this research used an approach of(Baron \& Kenny, 1986). The results of testing the mediating effect of the work engagement variable on career development through work motivation are explained as follows:

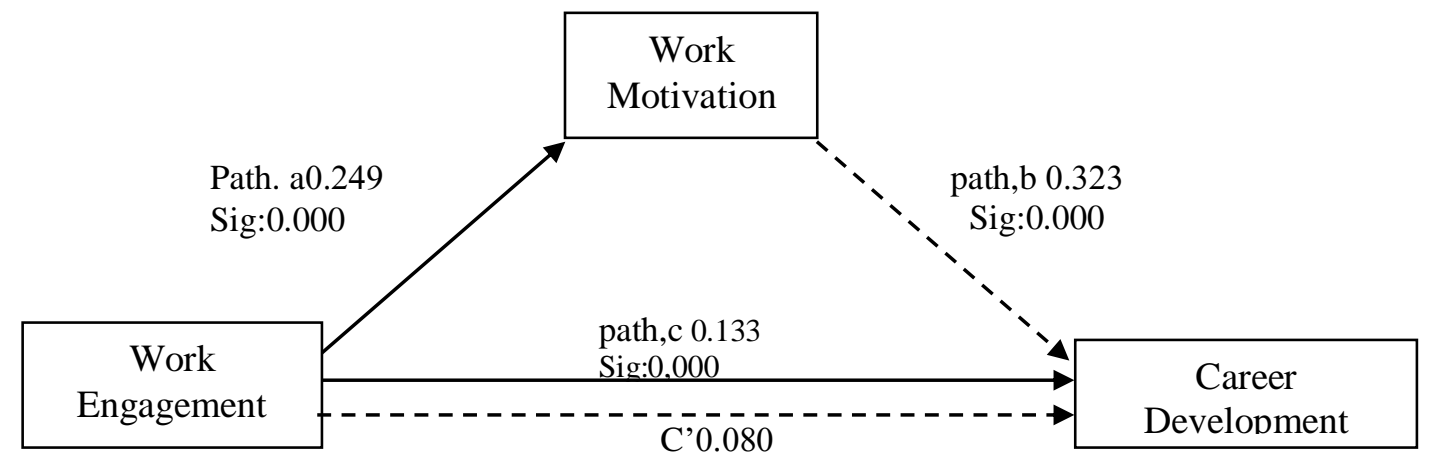

Figure 3. Mediating Effect of Work Motivation in H6 Information: 


$$
\begin{aligned}
\text { C' }^{\prime} & =\text { path } \mathrm{a} \times \text { path } \mathrm{b} \\
& =0.249 \times 0.323 \\
& =0.080
\end{aligned}
$$

Based on the test results above, it can be revealed that work engagement significantly affects career development through work motivation as a mediator. In addition, in the results of the previous direct effect test, the results stated that work engagement significantly affects work motivation, and work motivation significantly affects career development. Thus, testing this model proves that work motivation plays a role in the model as a partial mediator.

2. H7: Testing of the effect of job satisfaction on career development through work motivation aims to prove whether the influence is significant or not, with the following results.

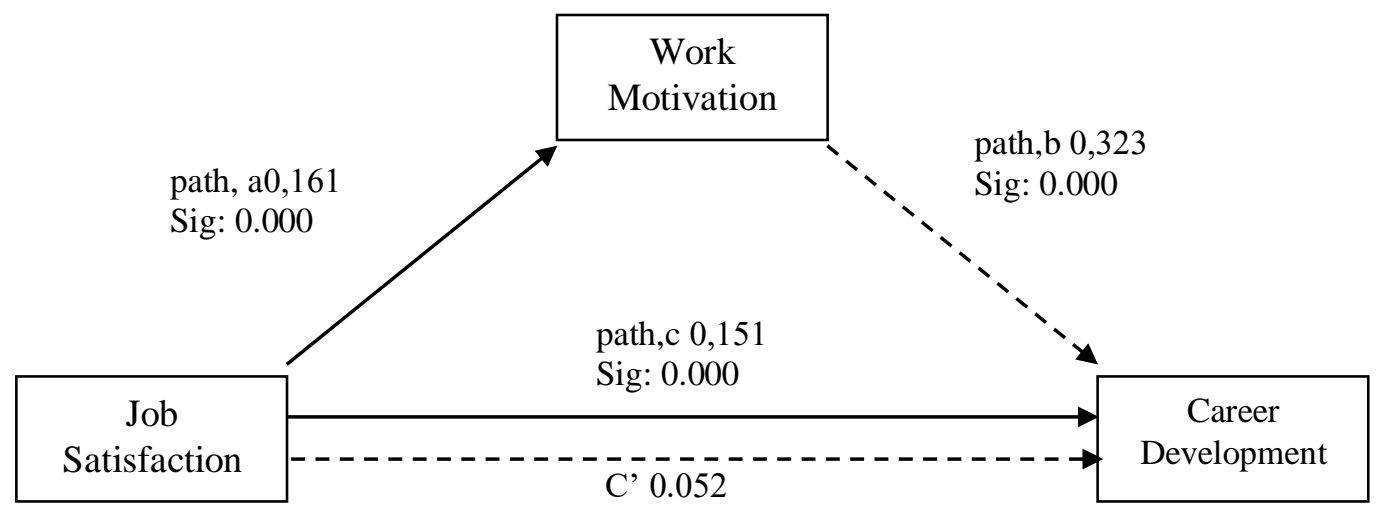

Figure 4. Mediating Effect of Work Motivation in H7

$$
\begin{aligned}
& \text { Information: } \\
& \begin{aligned}
\mathrm{C}^{\prime} \quad & =\text { path } \mathrm{a} \times \text { path } \mathrm{b} \\
& =0.161 \times 0.323 \\
& =0.052
\end{aligned}
\end{aligned}
$$

Based on the test results above, it can be revealed that job satisfaction significantly affects career development through work motivation as a mediator. In addition, in the results of the previous direct effect test, the results stated that job satisfaction significantly affects work motivation, and work motivation significantly affects career development. Thus, testing this model proves that work motivation plays a role in the model as a partial mediator.

\section{CONCLUSION}

The research results reveal that in the Setdakab Simeulue, it is proven that work engagement significantly affects employee career development, job satisfaction significantly affects career development, work engagement significantly affects work motivation, job satisfaction significantly affects work motivation, work motivation significantly affects career development, work engagement significantly affects career development through employee work 


\section{International Journal of Business Management and Economic Review}

Vol. 4, No. 04; 2021

ISSN: 2581-4664

motivation, and job satisfaction significantly affects career development through employee work motivation. From the results of the model test analysis, it was also found that the work motivation variable functions as a partial mediator. These findings have proven that in the career development model at the Setdakab Simeulue, it is necessary to strengthen work management and job satisfaction of employees so that they are able to boost their work motivation, and have an impact on strengthening the career development of employees. These results can be a good reference for academics and practitioners, especially those pursuing career development in organizations. Future researchers are expected to develop this tested model by adding other variables such as talent management and human capital management.

Some recommendations resulted from this research for the Setdakab Simeulue. In order to strengthen employee career development, by strengthening work engagement, what needs to be paid attention to is that employees must be able to know what is expected from a job so that the job can be done well. Then to increase employee job satisfaction, what must be ensured is that the leadership must provide opportunities for high-performing employees to get promotional opportunities. To increase work motivation, what needs to be paid attention to is the provision of life insurance following their position and working period, so that employees can meet their household needs.

\section{REFERENCES}

Albrecht, S. L. (2010). Handbook of Employee Engagement Perspectives, Issues, Research and Practice (C. L. Cooper, ed.). https://doi.org/https://doi.org/10.4337/9781849806374.00007

Amin, M., Ismail, W. K. W., Rasid, S. Z. A., \& Selemani, R. D. A. (2014). The impact of human resource management practices on performance Evidence from a Public University. The TQM Journal, 26(2), 125-142. https://doi.org/10.1108/TQM-10-2011-0062

Baron, R. M., \& Kenny, D. A. (1986). The moderator-mediator variable distinction in social psychological research: Conceptual, strategic, and statistical considerations. Journal of Personality and Social Psychology, 51(6), 1173-1182. https://doi.org/10.1037//00223514.51.6.1173

Bigliardi, B., Petroni, A., \& Dormio, A. I. (2005). Organizational socialization, career aspirations and turnover intentions among design engineers. Leadership \& Organization Development Journal, 26(6), 424-441. https://doi.org/https://doi.org/10.1108/01437730510617645

Freudenberger, H. J. (1974). Staff Burn-Out. Journal of Social, 30(1), 159-165. https://doi.org/https://doi.org/10.1111/j.1540-4560.1974.tb00706.x

Furnham, A., Petrides, K. V., Jackson, C. J., \& Cotter, T. (2002). Do personality factors predict job satisfaction? Personality and Individual Differences, 33(8), 1325-1342. https://doi.org/10.1016/S0191-8869(02)00016-8

Hagemann, G. (2013). Motivasi untuk Pembinaan Organisasi. Jakarta: PT. Pustaka Binaan Pressindo.

Herzberg, F., Mausner, B., \& Snyderman, B. B. (2011). The Motivation to Work. New Jersey: Transaction Publishers.

Kahn, W. A. (1990). Psychological conditions of personal engagement and disengagement at 
International Journal of Business Management and Economic Review

Vol. 4, No. 04; 2021

ISSN: 2581-4664

work. Academy of Management Journal, 33(4), 692-724.

Kaseger, R. G. (2013). Pengembangan Karir Dan Self-Efficacy Terhadap Kinerja Karyawan Pada PT. Matahari Department Store Manado Town Square. Jurnal EMBA, 1(4), 906-916. https://doi.org/https://doi.org/10.35794/emba.v1i4.2827

Koh, H. C., \& Boo, E. H. Y. (2001). The Link Between Organizational Ethics And Employee Job Satisfaction; A Study Of Managers In Singapore. Journal of Business Ethics, 29(4), 309-324. https://doi.org/10.1023/A:1010741519818

Robbins, S. P., Coulter, M. A., \& Cenzo, D. A. De. (2019). Fundamentals of Management (11th ed.). London: Pearson.

Robertson, I. T., \& Cooper, C. (2010). Full Engagement: the Integration of Employee Engagement and Psychological Well-Being. Leadership \& Organization Development Journal, 31(4), 324-336. https://doi.org/10.1108/01437731011043348

Saks, A. M. (2006). Employee engagement: Antecendents and consequences. Journal of Managerial Psychology, 21(7), 600-619.

Soetrisno, E. (2016). Manajemen Sumber Daya Manusia (Cetakan Ke). Jakarta: Prenada Media Gorup.

Sopiah, \& Sangadji, E. M. (2018). Manajemen Sumber Daya Manusia Strategik. Yogyakarta: Andi Publisher.

Wickramasinghe, V., \& Jayaweera, M. (2010). Impact of career plateau and supervisory support on career satisfaction: A study in offshore outsourced IT firms in Sri Lanka. The Career Development International, $15(6)$,

544-561. https://doi.org/https://doi.org/10.1108/13620431011084402

Zainal, V. R. (2015). Manajemen Sumber Daya Manusia Untuk Perusahaan: Dari Teori ke Praktik. In Jakarta: PT. Raja Grafindo Persadi (Edisi Keti). Depok: PT. Rajagrafindo Persada. 